\title{
HUBUNGAN STATUS GIZI DENGAN KEJADIAN ANEMIA PADA REMAJA PUTRI
}

\author{
Yulaeka \\ Akademi Kebidanan Permata Husada, Samarinda \\ Email : yuuchanyulaeka@gmail.com
}

Dikirim
Diterima
Diterbitkan

: 30 Juni 2020

: 10 Agustus 2020

: 3 September 2020

\begin{abstract}
Anemia is a condition when the levels of hemoglobin and erythrocytes are lower than normal. The normal value of hemoglobin in women is $12-16 \mathrm{~g} / \mathrm{dl}$ with erythrocytes from 3.5 to $4.5 \mathrm{jt} / \mathrm{mm} 3$. This study aimed to determine the relationship between nutritional status and Anemia of teenage girl. This research is analytic with cross sectional study design. The samples taken are 66 teenage girls, chosen by quote sampling. The data of this research used primary data obtained through checking up of body mass index with weighing and measuring height and hemoglobin level with venous blood sampling. The data analysis used univariate analysis and bivariate analysis used Chi-square test. The results showed 55,6\% of teenage girls in the category of normal nutritional status, $24,5 \%$ of teenage girls in the category of underweight nutritional status, and 19\% of teenage girls in the category of fat nutritional status. The results of this study indicate that there is a relationship between nutritional status and Anemia ( $p$ value 0.001).
\end{abstract}

Keywords $\quad$ : Anemia, teenage girls, nutritional status. 
Jurnal Kebidanan Mutiara Mahakam, Vol 8 , No 2, Tahun 2020, Hal 112-118

\section{PENDAHULUAN}

Anemia adalah suatu keadaan di mana kadar hemoglobin $(\mathrm{Hb})$ dalam darah lebih rendah dari nilai normal untuk kelompok orang yang bersangkutan. Penentuan anemia juga dapat dilakukan dengan mengukur hematokrit $(\mathrm{Ht})$. Nilai hematokrit rata-rata setara dengan tiga kali kadar hemoglobin. Batasan hemoglobin untuk menentukan apakah seseorang terkena anemia gizi besi atau tidak sangat dipengaruhi oleh umur. Untuk anak-anak umur 6 bulan-5 tahun, dapat dikatakan menderita anemia gizi besi apabila kadar hemoglobinnya kurang dari $11 \mathrm{~g} / \mathrm{dl}$, umur 6-14 tahun kurang dari $12 \mathrm{~g} / \mathrm{dl}$, dewasa laki-laki kurang dari $13 \mathrm{~g} / \mathrm{dl}$, dewasa perempuan tidak hamil kurang dari $12 \mathrm{~g} / \mathrm{dl}$, dan dewasa perempuan hamil kurang dari $11 \mathrm{~g} / \mathrm{dl}$ (Proverawati,2012).

Berdasarkan data survei aktual secara global tahun 2006 diketahui bahwa prevalensi anemia pada anak usia para sekolah, wanita hamil, dan wanita tidak hamil di dunia secara global berturutturut sebagai berikut 47,4\%,41,8\%, dan 30,2\%. Prevalensi anemia wanita tidak hamil di benua Afrika adalah 44,4\%, benua Asia 33,0\%, benua Eropa 15,2\%, benua Amerika Latin dan Caribbean (LAC) 23,5\%, Benua Amerika Utara 7,6\% dan Benua Oceania prevalensi anemia sebesar 20,2\%. Anemia defisiensi besi merupakan penyebab tersering dan terbesar di Indonesia dan Negara yang sedang berkembang (Prawirohardjo,2009). Angka prevalensi anemia di Indonesia, yaitu pada remaja wanita sebesar 26,50\%, pada wanita usia subur sebesar 26,9\%, pada ibu hamil sebesar 40,1\% dan pada balita sebesar 47,0\% (Burner, 2012).

Menurut BKKBN (2011) dalam Kajian Profil Penduduk Remaja (10 - 24 tahun), sebesar 14 persen baik remaja perempuan maupun remaja laki-laki yang mengetahui dengan benar mengenai anemia karena hemoglobin rendah. Pengertian anemia lainnya yang paling sering disebut adalah kurang darah (remaja perempuan $77 \%$ dan remaja pria 63\%). Anemia banyak dialami oleh remaja antara umur 15-19 tahun. Seiring karena pengetahuan yang terbatas tentang menstruasi mengakibatkan terjadinya anemia. Hal ini dikarenakan pada usia ini terjadi peningkatan kebutuhan zat besi akibat pertumbuhan, adanya menstruasi, sering membatasi konsumsi makan, serta pola konsumsinya sering menyalahi kaidah-kaidah ilmu gizi.

Remaja putri mempunyai risiko yang lebih tinggi terkena anemia daripada remaja putra. Pertama karena setiap bulan pada remaja putri mengalami haid. Seorang wanita yang mengalami haid yang banyak selama lebih dari lima hari dikhawatirkan akan kehilangan besi, sehingga membutuhkan besi pengganti lebih banyak daripada wanita yang haidnya hanya tiga hari dan sedikit. Kedua adalah karena remaja putri seringkali menjaga penampilan, keinginan untuk tetap langsing atau kurus sehingga berdiet dan mengurangi makan (Proverawati, 2012).

Secara umum ada beberapa faktor penyebab anemia yaitu kehilangan darah secara kronis atau banyak darah menstruasi, lama menstruasi, asupan zat besi tidak cukup, penyerapan yang tidak adekuat dan peningkatan kebutuhan akan zat besi, status gizi, penyakit malaria, infeksi-infeksi lain, serta pengetahuan tentang anemia. Faktor status gizi adalah faktor yang sangat berhubungan dengan 
Jurnal Kebidanan Mutiara Mahakam, Vol 8 , No 2, Tahun 2020, Hal 112-118

anemia. Status gizi pada remaja putri di Indonesia yaitu kurang zat gizi makro (karbohidrat, protein, lemak), kurang zat gizi mikro (vitamin, mineral). Pada manusia yang normal, kira-kira 20-25 mg besi per hari berasal dari besi hemolisis, dan hanya sekitar $1 \mathrm{mg}$ berasal dari makanan.

Di dalam tubuh manusia, jumlah zat besi sangat bervariasi tergantung pada umur, jenis kelamin, dan kondisi fisiologis tubuh. Pada orang dewasa sehat, jumlah zat besi diperkirakan lebih dari $4000 \mathrm{mg}$ dengan sekitar $2500 \mathrm{mg}$ ada dalam hemoglobin. Sebagian zat besi dalam tubuh (sekitar $1000 \mathrm{mg}$ ) disimpan di dalam hati dengan bentuk ferritin. Pada saat konsumsi zat besi dari makanan tidak cukup, zat besi ferritin dikeluarkan untuk memproduksi hemoglobin. Ketika tubuh tidak memproduksi zat besi dari makanan karena konsumsi kandungan makanan yang mengandung zat besi kurang, cadangan zat besi dari ferritin digunakan terus menerus, sehingga cadangan zat besi tersebut habis, hal tersebut yang bisa menyebabkan terjadinya anemia. Kurang zat gizi mikro dan makro menyebabkan tubuh menjadi kurus dan berat badan turun drastis, pendek, anemia, sakit terus menerus, sehingga sebagai calon ibu tidak sehat (Prawirohardjo,2009).

Menurut Prawirohardjo (2009), pencegahan anemia yaitu setiap remaja diberi sulfas ferrosus glukonas ferrosus cukup 1 tablet sehari. Remaja dianjurkan untuk makan lebih banyak protein dan sayur-sayuran yang mengandung banyak mineral serta vitamin.

Berdasarkan hasil studi pendahuluan yang dilakukan peneliti pada bulan Mei 2019 di SMAN 9 Samarinda dengan pemeriksaan $\mathrm{Hb}$ menggunakan Hemoque digital pada 10 responden, didapatkan 6 responden dengan kadar $\mathrm{Hb}$ kurang dari $12 \mathrm{gr} / \mathrm{dl}$ dan 4 responden memiliki kadar Hb lebih dari 12 gr/dl. Untuk sarapan pagi mereka lebih sering makan ketika istirahat pertama pada pukul 10.00 pagi dibandingkan makan pagi dirumah karena selalu buru - buru ke sekolah. Mereka lebih sering mengalami nyeri perut karena telat makan dan tidak sarapan pagi, lemas, lelah dan mengantuk. Keadaan ini selalu membuat konsentrasi belajar mereka terganggu.

Berdasarkan latar belakang diatas, maka peneliti tertarik untuk mengadakan penelitian tentang “Hubungan Status Gizi Dengan Kejadian Anemia Pada Remaja Putri”.

\section{METODE PENELITIAN}

Jenis penelitian ini adalah deskriptif korelatif, dan desain penelitian yang digunakan dalam penelitian ini adalah cross sectional. Dengan jumlah sampel yang digunakan sebesar 66 remaja putri usia 15 - 17 tahun dengan menggunakan teknik quota sampling. Penelitian dilakukan di SMAN 9 Samarinda pada bulan Mei 2019. Kriteria inklusi pada penelitian ini adalah remaja puteri yang tidak sedang menstruasi, tidak sedang sakit dan bersedia menjadi responden. Kriteria ekslusi adalah remaja putri yang tidak bersedia menjadi responden dan remaja putri yang sedang sakit. Variabel independen adalah status gizi, variabel dependen adalah kejadian anemia. Data yang digunakan adalah data primer dan sekunder. Intrumen penelitian menggunakan timbangan berat badan dan microtoa untuk status 
Jurnal Kebidanan Mutiara Mahakam, Vol 8 , No 2, Tahun 2020, Hal 112-118

gizi, serta hemoque digital untuk pemeriksaan kadar $\mathrm{Hb}$. Analisa data menggunakan analisis univariat dan analisa bivariat menggunakan uji chi square.

\section{HASIL DAN PEMBAHASAN}

1. Distribusi Frekuensi Status Gizi

Pada hasil penelitian didapatkan :

Tabel 1 Distrbusi Frekuensi Status Gizi Pada Remaja Putri

\begin{tabular}{|c|c|c|}
\hline Status Gizi & Frekuensi & Persentase (\%) \\
\hline Kurus & 16 & 24,5 \\
\hline Normal & 35 & 55,6 \\
\hline Gemuk & 12 & 19,0 \\
\hline Total & 63 & 100,0 \\
\hline
\end{tabular}

Berdasarkan tabel 1 menunjukkan bahwa sebanyak 55,6\% remaja putri dalam kategori status gizi normal, 24,5\% remaja putri dalam kategori status gizi kurus, dan 19\% remaja putri dalam kategori status gizi gemuk.

2. Distribusi Frekuensi Kejadian Anemia Pada Remaja Putri

Tabel 2 Distrbusi Frekuensi Kejadian Anemia Pada Remaja Putri

\begin{tabular}{lcc}
\hline Kejadian Anemia & Frekuensi & Persentase (\%) \\
\hline Anemia & 32 & 50,8 \\
Tidak Anemia & 31 & 49,2 \\
\hline Total & 63 & 100,0
\end{tabular}

Pada tabel 2 menunjukkan bahawa remaja puteri yang mengajalami anemia sebanyak 50,8\% dan remaja putri yang tidak anemia sebanyak $49,2 \%$.

3. Analisis Bivariat

Tabel 3 Hubungan Status Gizi dengan Kejadian Anemia Pada Remaja Putri

\begin{tabular}{|c|c|c|c|c|c|}
\hline \multirow{3}{*}{ Status Gizi } & \multicolumn{4}{|c|}{ Kejadian Anemia } & \multirow{3}{*}{ p-value } \\
\hline & \multicolumn{2}{|c|}{ Anemia } & \multicolumn{2}{|c|}{ Tidak anemia } & \\
\hline & $\mathbf{f}$ & $\%$ & f & $\%$ & \\
\hline Kurus & 13 & 81,2 & 3 & 18,8 & 0,001 \\
\hline Normal & 18 & 51,4 & 17 & 48,6 & \\
\hline Gemuk & 1 & 8,3 & 11 & 91,7 & \\
\hline Total & 32 & 50,8 & 31 & 49,2 & \\
\hline
\end{tabular}

Pada tabel 3 menunjukkan bahwa remaja putri yang mengalami anemia dengan status gizi kurus sebanyak $81,2 \%$, remaja putri yang mengalami anemia dengan status gizi normal sebanyak $51,4 \%$, dan remaja putri yang mengalami anemia dengan status gizi gemuk sebanyak $8,3 \%$. 
Jurnal Kebidanan Mutiara Mahakam, Vol 8 , No 2, Tahun 2020, Hal 112-118

Sedangkan remaja putri yang tidak anemia dengan status gizi kurus sebanyak $18,8 \%$, remaja putri yang tidak anemia dengan status gizi normal sebanyak 48,6\%, dan remaja putri yang tidak anemia dengan status gizi gemuk sebanyak $91,7 \%$.

Status gizi merupakan keadaan kesehatan tubuh seseorang atau sekelompok orang yang diakibatkan oleh konsumsi, penyerapan (absorpsi), dan penggunaan zat gizi makanan didalam tubuh. Status gizi merupakan faktor penting untuk menilai seseorang dalam keadaan sehat atau tidak menderita penyakit akibat gangguan gizi baik secara mental maupun fisik. Ketidakseimbangan dalam penyediaan pangan menyebabkan masalah dalam pemenuhan gizi, yakni masalah gizi kurang dan masalah gizi lebih (Proverawati,2012).

Pada hasil penelitian didapatkan lebih dari setengah responden mengalami anemia. Hal ini disebabkan oleh masalah asupan nutrisi. Remaja putri masih banyak yang mengabaikan nutrisi seimbang sehingga dapat mengakibatkan terjadinya anemia. Jumlah zat gizi seimbang didalam tubuh tidak mencukupi karena jumlah lemak yang berlebih. Terjadi metabolisme zat gizi didalam tubuh yang tidak seimbang, keadaan ini dapat menyebabkan terjadinya anemia.

Hubungan antara status gizi dengan kejadian anemia ini dilakukan dengan menggunakan rumus Chi square, didapatkan $p$-value sebesar 0,001 pada tarif signifikan 0,05. Karena $p$-value < 0,05 maka Ho ditolak dan Ha diterima, sehingga ada hubungan antara status gizi dengan kejadian anemia pada remaja putri di Kota Samarinda.

Menurut Supariasa (2012), perubahan biokimia terjadi di dalam darah karena rendahnya zat-zat gizi didalam darah, berupa rendahnya tingkat hemoglobin, serum vitamin A dan karoten. Terjadi beberapa hasil metabolisme seperti asam laktat dan piruvat pada kekurangan vitamin. Apabila keadaan tersebut berlangsung lama, maka akan terjadi perubahan fungsi tubuh seperti tanda-tanda syaraf yaitu kelemahan, pusing, kelelahan, nafas pendek, dan lain-lain.

Fase remaja adalah fase dimana sepenuhnya belum matang, baik secara fisik, kognitif, dan psikososial. Karena dalam masa pencarian identitas ini, remaja cepat sekali terpengaruh oleh lingkungan yang buruk terutama pada pola nutrisi. Remaja siswi yang memiliki status gizi kurus dapat disebabkan oleh rendahnya asupan pemenuhan zat nutrisi dalam tubuh. Rendahnya asupan pemenuhan zat nutrisi dalam tubuh disebabkan kegemaran yang tidak lazim, seperti pilihan untuk menjadi vegetarian, atau food fadism. Selain itu kesibukan menyebabkan mereka memilih makan di luar, atau hanya menyantap kudapan sehingga asupan nutrisi yang dibutuhkan tubuh tidak terpenuhi.

Hal ini sesuai dengan teori yang dikemukan Banudi (2012), kurangnya gizi pada remaja karena dalam kondisi ini mereka ingin terlihat ramping. Seringkali cara yang dilakukan remaja tidak tepat, misalnya dengan melakukan pembatasan makanan atau diet, konsumsi obat pelangsing, mengadopsi obat pelangsing, dan memutahkan kembali makanan. 
Jurnal Kebidanan Mutiara Mahakam, Vol 8 , No 2, Tahun 2020, Hal 112-118

Hal ini didukung oleh penelitian Dieny (2014), ada sekitar 72,9\% remaja putri di Yogyakarta yang mempunyai status gizi baik, namun melakukan upaya penurunan berat badan, sedangkan 5,9\% remaja yang berstatus gizi kurang juga tetap berupaya melakukan penurunan berat badan demi mendapatkan berat badan yang ideal.

Hal ini sesuai dengan hasil penelitian Kurnia Fitriani (2013) yang menyatakan bahwa asupan energi kurang dari kebutuhan dalam jangka waktu tertentu akan menyebabkan terjadi penurunan status gizi, bila asupan energi seimbang akan membantu memelihara status gizi normal.

Hal ini pun didukung oleh penelitian Burner (2012) yang menyatakan bahwa ada hubungan yang bermakna antara status gizi dengan kejadian anemia, didapatkan p-value sebesar 0,000. Di Indonesia banyak remaja yang tidak membiasakan sarapan dan kurang mengkonsumsi makanan yang mengandung zat gizi mencapai 50\%, oleh sebab itu remaja di Indonesia mudah menderita anemia. Kebiasaan yang sering dilakukan oleh kebanyakan remaja baik remaja putra maupun remaja putri mengkonsumsi makanan yang kurang bergizi misalnya seperti es, coklat, gorengan, permen dan makan tidak teratur karena melakukan aktivitas belajar yang padat sering menyebabkan terjadi gangguan pada pencernaan, sehingga proses penyerapan zat besi dalam tubuh terganggu.

\section{SIMPULAN}

1. Remaja putri di SMAN 9 Samarinda sebanyak $(55,6 \%)$ mempunyai status gizi dalam kategori normal.

2. Remaja puteri di SMAN 9 Samarinda yang mengajalami anemia sebanyak 50,8\% dan remaja putri yang tidak anemia sebanyak $49,2 \%$.

3. Hasil uji statistic didapatkan p-value 0,001, sehingga dapat disimpulkan bahwa terdapat hubungan antara status gizi dengan kejadian anemia pada remaja putri di SMAN 9 Samarinda tahun 2019.

\section{DAFTAR PUSTAKA}

Banudi, La. (2013). Gizi Kesehatan Reproduksi. Jakarta: EGC

Burner. (2012). Faktor-Faktor Yang Berhubungan Dengan Kejadian Anemia Pada Remaja Putri. Jurnal Ilmu Pendidikan. (Online), (http://repository.usu.ac.id/ ), diakses tanggal 15 November 2014.

Dieny, Fillah. F. (2014). Permasalahan Gizi Pada Remaja Putri. Yogyakarta: Graha Ilmu Fitriani, Kurnia. (2015). Hubungan Status Gizi Dengan Kejadian Anemia Pada Remaja Putri. http://ejournal-s1.undip.ac.id.

Prawirohardjo, Sarwono. (2009). Ilmu Kandungan. Jakarta: PT Bina Pustaka Sarwono Prawirohardjo. 
Jurnal Kebidanan Mutiara Mahakam, Vol 8 , No 2, Tahun 2020, Hal 112-118

Proverawati. (2012). Anemia Dan Anemia Kehamilan. Yogyakarta: Nuha Medika.

Pusdu-BKKBN. (2011). Kajian Profil Penduduk Remaja (10-24 thn). Pusat Penelitian dan Pengembangan Kependudukan - BKKBN

Supariasa, I. D. N., Bakri, B. \& Fajar, I. (2012). Penilaian Status Gizi. Jakarta: Penerbit Buku EGC. 